\title{
Parasitoides associated with Anastrepha fraterculus (Diptera: Tephritidae) in native fruits: first record of Aganaspis nordlanderi (Hymenoptera: Figitidae) in the state of Santa Catarina
}

\author{
Janaína Pereira dos $\operatorname{Santos}^{1} \&$ Jorge Anderson Guimarães ${ }^{2}$
}

\begin{abstract}
With the objective of studying the entomofauna of microhymenoptera parasitoids associated with $A$. fraterculus, we collected fruits from native fruit trees in Caçador, State of Santa Catarina, Brazil. We evaluated fruit from Eugenia involucrata, E. uniflora, Campomanesia xanthocarpa, Psidium cattleyanum (red and yellow), and Rubus sp. For each fruit tree species, we collected 40 fruits from five plants, for a total of 200 fruits per species. The fruits were maintained in plastic boxes containing sterilized sand to obtain puparia, which subsequently, were maintained in cages until the emergence of flies and/or parasitoids. In the fruits collected, we encountered puparia of A. fraterculus, from which emerged Aganaspis nordlanderi, A. pelleranoi (Figitidae: Eucoilinae), Doryctobracon brasiliensis and D. areolatus (Braconidae: Opiinae). This is the first record of the species $A$. nordlanderi in the State of Santa Catarina. This study also represents the first record of $A$. fraterculus as host of $A$. nordlanderi.
\end{abstract}

Index terms: South American fruit fly, biological control, new record.

\section{Parasitodes associados à Anastrepha fraterculus (Diptera: Tephritidae) em frutos nativos: primeiro registro de Aganaspis nordlanderi (Hymenoptera: Figitidae) em Santa Catarina}

Corresponding author: janapereira@epagri.sc.gov.br

Received: March 30, 2017. Accepted :April 23, 2017.

Copyright: All the contents of this journal, except where otherwise noted, is licensed under a Creative Commons Attribution License.
Resumo- Com o objetivo de estudar a entomofauna de microimenópteros parasitoides associados à $A$. fraterculus foram realizadas coletas de frutos nativos no município de Caçador, Santa Catarina, Brasil. Foram avaliados frutos de Eugenia involucrata, E. uniflora, Campomanesia xanthocarpa, Psidium cattleyanum (vermelho e amarelo), e Rubus sp. De cada espécie frutífera, foram coletados 40 frutos de cinco plantas, totalizando 200 frutos por espécie frutífera. Os frutos foram acondicionados em caixas plásticas contendo areia esterilizada para a obtenção de pupários, que, posteriormente, foram mantidos em gaiolas até à emergência de moscas e/ou parasitoides. Dos frutos coletados, obtiveram-se pupários de A. fraterculus, dos quais emergiram Aganaspis nordlanderi, A. pelleranoi (Figitidae: Eucoilinae), Doryctobracon brasiliensis e D. areolatus (Braconidae: Opiinae). A espécie $A$. nordlanderi foi registrada pela primeira vez em Santa Catarina. No Brasil, trata-se do primeiro registro de $A$. fraterculus como hospedeira de $A$. nordlanderi. Termos para indexação: Mosca-das-frutas-sul-americana, controle biológico, novo registro.

${ }^{1}$ Agronomist, D.Sc. Researcher at EPAGRI - Experimental Station of Caçador, PO box 591, 89500-000, Caçador-SC, Brazil. E-mail: janapereira@epagri.sc.gov.br ${ }^{2}$ Biologist, D.Sc. Researcher at Embrapa Hortaliças, Brasília-DF. E-mail: jorgeanderson@embrapa.br 
The South American fruit fly, Anastrepha fraterculus (Wiedemann, 1830) (Diptera: Tephritidae) is considered the most important insect pest of temperate fruit crops in the Southern of Brazil (NORA; HICKEL, 2006). In the state of Santa Catarina, A. fraterculus is the species of Tephritidae more frequent and abundant (GARCIA; NORRBOM, 2011). In Brazil, the main practices adopted by fruit growers to supress fruit flies populations include the use of toxic baits and spraying with insecticides (BORGES et al., 2015). However, due to pressure from importing countries demanding an absence of pests and chemical residues, thus limiting the exportation of fresh fruit (PARANHOS et al., 2007), along with the increased environmental awareness of Brazilian consumers and producers, the management of this insect pest has been improved (COSTA et al., 2007). As such, other control strategies have been adopted, including the use of biological control through native hymenopteran parasitoids, which have shown promising results in controlling various agricultural pests around the world (PARANHOS et al., 2007). Among the parasitoids used to control fruit flies (Tephritidae) infestation, the subfamilies Eucoilinae (Figitidae) and Opiinae (Braconidae) are among the most commonly used, due to their efficiency in natural conditions (GUIMARÃES et al., 2003). The detection and quantification of insect pest populations in orchards, as well as their parasitoids, are essential steps in the implementation of control strategies that involve integrated pest management (ALUJA et al., 2012). Another important aspect to be considered is the fruiting of native host plants occurring in natural forests, as they influence the size of the fruit fly population that could colonize nearby orchards (NORA;HICKEL, 2006) and enable almost continuous insect reproduction. However, along with monitoring fruit flies with traps containing food lure, it is essential to complement this data by collecting fruit samples to evaluate damage, detect the presence of larvae, the level of infestation, and the association of a particular species with its host (SÁ et al., 2008), as well as determine the level of parasitism. Therefore, studies on parasitoid species diversity can contribute to the search for alternative control methods for fruit flies, as they provide important information on the fruit tree species that act as hosts for these natural enemies. In this context, we collected fruits from native fruit trees with the objective of identifying the parasitoids associated with $A$. fraterculus. This study was conducted at Epagri's Experimental Research Station in Caçador, State of Santa Catarina from October 2015, until April 2016. We evaluated fruits from Eugenia involucrata DC. (Cherry of the Rio Grande), Eugenia uniflora L. (Surinam cherry), Campomanesia xanthocarpa O.Berg (guabiroba), Psidium cattleyanum Sabine (strawberry guava and yellow strawberry guava) (Myrtaceae family), and Rubus sp. (blackberry) (Rosaceae family). The plants did not receive any phytosanitary treatment and the fruits were randomly collected from the ground and the tree canopy when ripe. For each fruit tree species, we collected 40 fruits from five plants, for a total of 200 fruits per species. After collection, the fruits were transported in paper bags to the laboratory. They were then transferred to plastic boxes $(34.5 \times 11.5$ $\mathrm{x} 2.0 \mathrm{~cm}$ ) containing a layer of approximately $1 \mathrm{~cm}$ of sterilized sand (40 fruits per container) and maintained in climatized room, under the following conditions: temperature $\left(25 \pm 1^{\circ} \mathrm{C}\right)$, relative humidity $(60 \pm 10 \%)$, and a photoperiod of 12:12 (L:D) h. At 7, 14, and 21 days, the sand was sieved to collect and count puparia. The puparia were then transferred to Petri dishes containing sterilized sand as substrate and placed in cages ( $40.0 \times 51.5 \times 29.0$ $\mathrm{cm})$ until the emergence of flies and/or parasitoids. The obtained specimens were stored in plastic containers (50 $\mathrm{mL}$ ) containing 70\% alcohol, and later examined under a stereoscopic microscope for species identification, based on dichotomous keys for the species Anastrepha (ZUCCHI, 2000) and the parasitoids Braconidae (CANAL;ZUCCHI, 2000) and Figitidae (GUIMARÃES et al., 2000). We found 1,344 puparia, from which emerged 752 fruit flies (all of which were $A$. fraterculus) and 12 parasitoids. We did not observe the development of fruit flies in blackberry or Surinam cherry fruit. Parasitoids were found only in fruits from guabiroba and strawberry guava. From the guabiroba, we identified only one specimen of Aganaspis nordlanderi Wharton, 1998 (Figitidae: Eucoilinae). From strawberry guava, we observed the greatest diversity of parasitoids, with six specimens of Doryctobracon brasiliensis (Szépligeti, 1911), two Doryctobracon areolatus (Szépligeti, 1911) (Braconidae: Opiinae), two A. nordlanderi, and one Aganaspis pelleranoi (Brèthes, 1924) (Figitidae: Eucoilinae). Based on Nora et al. (2000), the level of parasitism in the state of Santa Catarina is variable and influenced by the host plant species in which the fruit fly develops. According to the authors, the main native hosts of host parasitoids of fruit flies are Psidium spp. (cattley guavas), Annona cacans Warm. (Araticum), Celtis iguanaea (Jacq.) Sarg. (Iguana hackberry), Acca sellowiana (O.Berg) Burret (feijoa), Campomanesia spp. (guabiroba), and Campomanesia guazumifolia (Cambess.) O.Berg. ('sete-capotes'). Guimarães et al. (1999) undertook studies across 51 municipalities in the South, Centre-west, Southeast, North, and Northeast of Brazil, in order to evaluate the geographic distribution, associated hosts, and the percentage of parasitism of Eucoilinae species. In the South, the study found a lower level of diversity of Eucoilinae species, represented only by the species A. pelleranoi and Odontossema anastrephae Borgmeier, 1935. The only specimens collected in Caçador were A. pelleranoi. Garcia and Corseuil (2004), in the Western of the state of Santa Catarina, registered eight parasitoids associated with $A$. fraterculus, with the most 
common in the region being $A$. pelleranoi $(25.6 \%)$, followed by $D$. brasiliensis $(21.1 \%)$ and $D$. areolatus $(18.6 \%)$. The authors found that cattley guava was a common host for the three species, which is consistent with the present study. Garcia and Norrbom (2011) registered 20 species of host plants for $A$. fraterculus also in the Western Santa Catarina, of which 11 belong to the Myrtaceae family. The study also showed that cattley guava was the most frequently infested host. The representatives of Braconidae family (Opiinae) behave as koinobiont endoparasitoids of cyclorrhaphous Diptera larva-pupa and are among the most frequently collected in Brazil (CANAL; ZUCCHI, 2000). Around the world, approximately 1,300 species of Opiinae (WHARTON et al., 1998) have been described, with the native species of Doryctobracon, Utetes and Opius being the main species responsible for natural parasitism of fruit flies (OVRUSKI et al., 2000). In the State of Santa Catarina, the following Braconidae (Opiinae) species have been registered: Microcrasis lonchaeae (Costa Lima, 1937) (CANAL; ZUCCHI, 2000); Utetes tomoplagiae (COSTA LIMA, 1937) (NORA et al., 2000); Utetes anastrephae (Viereck, 1913) (GARCIA; COURSEUIL, 2004; ZUCCHI, 2008); D. areolatus, D. brasiliensis and Opius bellus Gahan, 1930 (NORA et al., 2000; GARCIA; COURSEUIL, 2004; ZUCCHI, 2008). The representatives of Figitidae family (Eucoilinae) behave as koinobiont endoparasitoids of larva-pupa (GUIMARÃES et al., 1999) of Tephritidae and Lonchaeidae flies (GUIMARÃES et al., 2003). They are part of the Cynipoidea superfamily that includes approximately 3,000 species from 255 genera (GUIMARÃES et al., 1999, 2000). In Brazil, Eucoilinae is the most diverse subfamily of Figitidae, with approximately 55 species, distributed among 29 genera (GUIMARÃES et al., 1999, 2000). Various Eucoilinae species are parasitoid to fruit flies from the Tephritidae family, and therefore act as important agents for natural biological control of these pests (GUIMARÃES et al., 1999, 2000; OVRUSKI et al., 2000). The species Aganaspis daci (Weld, 1951) and A. pelleranoi are used most often in biological control programs of fruit flies (WHARTON et al., 1998; OVRUSKI et al., 2000). In Brazil, the Eucoilinae species A. nordlanderi, A. pelleranoi, Lopheucoila anastrephae (Rohwer, 1919), $O$. anastrephae, and Trybliographa sp. have been associated with the fruit flies Anastrepha spp., Ceratitis capitata (WIEDEMANN, 1824), and Lonchaeidae, in 34 fruit tree species, distributed across 15 botanical families (GUIMARÃES et al., 1999; 2000; 2003). The following Figitidae (Eucoilinae) species have been registered in Santa Catarina: $O$. anastrephae (GUIMARÃES et al., 1999; 2000; GARCIA; COURSEUIL, 2004); Odontosema albinerve Kieffer, 1909 (ZUCCHI, 2008); L. anastrephae (GARCIA;COURSEUIL, 2004); and A. pelleranoi (GUIMARÃES et al., 1999; 2000; NORA et al., 2000;
GARCIA;COURSEUIL, 2004; ZUCCHI, 2008). Until the present study, $A$. nordlanderi had only been documented in Brazil in studies undertaken in the States of Amazonas (GUIMARÃES et al., 1999, 2000; ZUCCHI, 2008; COSTA et al., 2009; RONCHI-TELES et al., 2011; DUTRA et al., 2013), São Paulo (GUIMARÃES et al., 1999, 2000; ZUCCHI, 2008), Goiás (BRAGA-FILHO et al., 2001), Mato Grosso do Sul, and Espírito Santo (ZUCCHI, 2008). A. nordlanderi is distributed throughout the Neotropical region, occurring in Costa Rica, Brazil (OVRUSKI et al, 2000; GUIMARÃES et al, 2003), Colombia (GUIMARÃES et al, 2003), Mexico, Belize, Guatemala, El Salvador, Panama, Venezuela, Peru, Bolivia and Argentina (GUIMARÃES et al, 2003). The species was described in 1998 by Wharton, based on specimens from Costa Rica (WHARTON et al., 1998). In Brazil, $A$. nordlanderi was first registered in 1998, in the state of Amazonas, acting as a parasitoid of the fruit flies Anastrepha bahiensis Lima, 1937, Anastrepha striata Schiner, 1868 (Tephritidae), and Neosilba sp. (Lonchaeidae) (GUIMARÃES;PERIOTO, 1998). This study represents the first record of $A$. nordlanderi in Santa Catarina, thus increasing the range of the species into the Southern of Brazil. This is also the first record of the parasitoid in association with A. fraterculus in Brazil.

\section{References}

ALUJA, M.; ORDANO, M.; GUILLÉN, L.; RULL, J. Understanding long-term fruit fly (Diptera: Tephritidae) population dynamics: implications for area wide management. Journal of Economic Entomology, Lanham, v.105, n.3, p.823-836, 2012.

BORGES, R.; MACHOTA JUNIOR, R.; BOFF, M.I.C.; BOTTON, M. Efeito de iscas tóxicas sobre Anastrepha fraterculus (Wiedemann) (Diptera: Tephritidae). BioAssay, Piracicaba, v.10, n.3, p.1-8, 2015.

BRAGA-FILHO, J.R.; VELOSO, V.R.S.; NAVES, R.V.; FERREIRA, G.A. Entomofauna associada aos frutos do bacupari, Salacia crassifolia (Mart.) Peyr, nos cerrados do Brasil Central. Pesquisa Agropecuária Tropical, Goiânia, v.31, n.1, p.47-54, 2001.

CANAL, N.A.; ZUCCHI, R.A. Parasitóides - Braconidae. In: MALAVASI, A.; ZUCCHI, R.A. (Org.). Moscasdas-frutas de importância econômica no Brasil: conhecimento básico e aplicado. Ribeirão Preto: Holos, 2000. p.119-126. 
COSTA, R.I.F.; SILVA, C.G. DA S.; MARCHIORI, C.H.; AMARAL, B.B.; POLETTI, M.M.; TORRES, L.C. Parasitismo em Anastrepha sp. (Diptera: Tephritidae) por Aganaspis pelleranoi (Brèthes, 1924) e Dicerataspis sp. (Hymenoptera: Figitidae: Eucoilinae). Ciência e Agrotecnologia, Lavras, v.31, n.3, p.720-723, 2007.

COSTA, S.G.M.; QUERINO, R.B.; RONCHI-TELES, B.; PENTEADO-DIAS, A.M.M.; ZUCCHI, R.A. Parasitoids diversity (Hymenoptera: Braconidae and Figitidae) on frugivorous larvae (Diptera: Tephritidae and Lonchaeidae) at Adolpho Ducke Forest Reserve, Central Amazon Region, Brazil. Brazilian Journal of Biology, São Carlos, v.69, n.2, p.363-370, 2009.

DUTRA, V.S.; RONCHI-TELES, B.; GARCIA, M.V.B.; ADAIME, R.; SILVA, J.G. Native hosts and parasitoids associated with Anastrepha fractura and other Anastrepha species (Diptera: Tephritidae) in the Brazilian Amazon. Florida Entomologist, Gainesville, v.96, n.1, p.270-273. 2013.

GARCIA, F.R.M.,; NORRBOM, A.L. Tephritoid flies (Diptera, Tephritoidea) and their plant hosts from state of Santa Catarina in Southern Brazil. Florida Entomologist, Gainesville, v.94, n.2, p.151-157. 2011.

GARCIA, F.R.M.; CORSEIUL, E. Native hymenopteran parasitoids associated with fruit flies (Diptera: Tephritidae) in Santa Catarina State, Brazil. Florida Entomologist, Gainesville, v.87, n.4, p.517-521, 2004.

GUIMARÃES, J.A.; DIAZ, N.B.; ZUCCHI, R.A. Parasitóides - (Figitidae: Eucoilinae). In: MALAVASI, A.; ZUCCHI, R.A. (Org.). Moscas-das-frutas de importância econômica no Brasil: conhecimento básico e aplicado. Ribeirão Preto: Holos, 2000. p.127-134.

GUIMARÃES, J.A.; GALLARDO, F.E.; DIAZ, N.B.; ZUCCHI, R.A. Eucoilinae species (Hymenoptera: Cynipoidea: Figitidae) parasitoids of fruit-infesting dipterous in Brazil: identity, geographical distribution and host associations. Zootaxa, Auckland, v.278, n.1, p.1-23, 2003.

GUIMARÃES, J.A.; PERIOTO, N.W. Primeira ocorrência de Aganaspis nordlanderi Wharton, 1998 (Hymenoptera: Figitidae: Eucoilinae) no Brasil. In: REUNIÃO ANUAL DO INSTITUTO BIOLÓGICO, 11., 1998, São Paulo. Anais... São Paulo: Instituto Biológico, 1998. p.44.
GUIMARÃES, J.A.; ZUCCHI, R.A.; DIAZ, N.B.; SOUZA FILHO, M.F.; UCHÔA-FERNADES, M.A. Espécies de Eucoilinae (Hymenoptera: Figitidae) parasitóides de larvas frugívoras (Diptera: Tephritidae e Lonchaeidae) no Brasil. Anais da Sociedade Entomológica do Brasil, Londrina, v.28, n.2, p.263-273, 1999.

NORA, I.; HICKEL, E. Pragas da macieira: dípteros e lepidópteros. In: EPAGRI(Org.). A cultura da macieira. Florianópolis: GMC/Epagri, 2006. p.463-486.

NORA, I.; HICKEL, E.R.; PRANDO, H.F. Moscasdas-frutas nos estados brasileiros: Santa Catarina. In: MALAVASI, A.; ZUCCHI, R.A. (Org.). Moscasdas-frutas de importância econômica no Brasil: conhecimento básico e aplicado. Ribeirão Preto: Holos, 2000. p.271-276.

OVRUSKI, S.M.; ALUJA, M.; SIVINSKI, J.; WHARTON, R. Hymenoptera parasitoids on fruit-infesting Tephritidae (Diptera) in Latin America and Southern United States: diversity, distribution, taxonomic status and their use in fruit fly biological control. Integrated Pest Management Reviews, Dordrecht, v.5, n.2, p.81-107, 2000.

PARANHOS, B.A.J.; WALDER, J.M.M.; ALVARENGA, C.D. Parasitismo de larvas da mosca-do-mediterrâneo por Diachasmimorpha longicaudata (Ashmead) (Hymenoptera: Braconidae) em diferentes cultivares de goiaba. Neotropical Entomology, Londrina, v.36, n.2, p.243-246, 2007.

RONCHI-TELES, B.; DUTRA, V.S.; TREGUE-COSTA, A.L.; AGUIAR-MENEZES, E.L.; MESQUITA, A.C.A.; SILVA, J.G. Natural host plants and native parasitoids associated with Anastrepha pulchra and other Anastrepha species (Diptera: Tephritidae) in Central Amazon, Brazil. Florida Entomologist, Gainesville, v.94, n.2, p.347-349, 2011.

SÁ, R.F. DE; CASTELLANI, M.A.; NASCIMENTO, A.S.; BRANDÃO, M.H.S.T.; SILVA, A.N.; PÉREZMALUF, R. Índice de infestação e diversidade de moscadas-frutas em hospedeiros exóticos e nativos no pólo de fruticultura de Anagé, BA. Bragantia, Campinas, v.67, n.2, p.401-411, 2008.

WHARTON, R.A.; OVRUSKI, S.M.; GILSTRAP, F.E. Neotropical Eucoilidae (Cynipoidea) associated with fruit infesting Tephritidae, with new records from Argentina, Bolivia and Costa Rica. Journal of Hymenoptera Research, Washington, v.7, p.102-115, 1998. 
ZUCCHI, R.A. Fruit flies in Brazil (Anastrepha species and their hosts plants, and parasitoids). Piracicaba: ESALQ/USP, 2008. Disponível em: <http://www.lea. esalq.usp.br/anastrepha $>$. Acesso em: 30 jun. 2016.
ZUCCHI, R.A. Taxonomia. In: MALAVASI, A.; ZUCCHI, R.A. (Orgs.). Moscas-das-frutas de importância econômica no Brasil: conhecimento básico e aplicado. Ribeirão Preto: Holos, 2000. p.13-24. 